\title{
ON THE FORMATION OF NIACIN (VITAMIN B3) AND PYRIDINE CARBOXYLIC ACIDS IN INTERSTELLAR MODEL ICES
}

\author{
Brandon M. McMurtry, Andrew M. Turner, Sean E. J. Saito, and Ralf I. Kaiser ${ }^{*}$
}

W. M. Keck Research Laboratory in Astrochemistry, University of Hawaii at Manoa, Honolulu, Hawaii, HI 96822

Department of Chemistry, University of Hawaii at Manoa, Honolulu, Hawaii, HI 96822, US 


\begin{abstract}
The formation of pyridine carboxylic acids in interstellar ice grains was simulated by electron exposures of binary pyridine $\left(\mathrm{C}_{5} \mathrm{H}_{5} \mathrm{~N}\right)$-carbon dioxide $\left(\mathrm{CO}_{2}\right)$ ice mixtures at $10 \mathrm{~K}$ under contamination-free ultrahigh vacuum conditions. Chemical processing of the pristine ice and subsequent warm-up phase was monitored on line and in situ via Fourier transform infrared spectroscopy to probe for the formation of new radiation induced species. In the infrared spectra of the irradiated ice, bands assigned to nicotinic acid (niacin; vitamin $\mathrm{B} 3 ; m-\mathrm{C}_{5} \mathrm{H}_{4} \mathrm{NCOOH}$ ) along with 2,3-, 2,5-, 3,4-, and 3,5-pyridine dicarboxylic acid $\left(\mathrm{C}_{5} \mathrm{H}_{3} \mathrm{~N}(\mathrm{COOH})_{2}\right)$ were unambiguously identified along with the hydroxycarbonyl (HOCO) radical. Our study suggests that the reactive pathway responsible for pyridine carboxylic acids formation involves a HOCO intermediate, which forms through the reaction of suprathermal hydrogen ejected from pyridine with carbon dioxide. The newly formed pyridnyl radical may then undergo radical-radical recombination with a hydroxycarbonyl radical to form a pyridine carboxylic acid.
\end{abstract}




\section{INTRODUCTION}

Nicotinic acid $\left(m-\mathrm{C}_{5} \mathrm{H}_{4} \mathrm{NCOOH}\right)$ - commonly known as vitamin B3 or niacin - along with the other two monosubstituted pyridine carboxylic acids, picolinic acid $\left(o-\mathrm{C}_{5} \mathrm{H}_{4} \mathrm{NCOOH}\right)$ and isonicotinic acid ( $p-\mathrm{C}_{5} \mathrm{H}_{4} \mathrm{NCOOH}$; Figure 1), have recently been identified in the carbonaceous chondrites Murchison [1,2] and Tagish Lake [3] at levels of typically 7 ppm. A follow-up study by Smith, et al. [4] on CM2-type carbonaceous chondrites revealed the presence of three monosubstituted pyridine carboxylic acid isomers at levels from 163 to $1377 \mathrm{ppb}$ along with three disubstituted pyridine carboxylic acids (2,5-, 3,4-, and 3,5-) (Figure 1). These findings build upon the complex inventory of organic molecules detected within chondrites [5] including (polycyclic) aromatic hydrocarbons [6,7], nucleobases [8], sugars [9,10], and amino acids [1113]. Detailed ${ }^{13} \mathrm{C} /{ }^{12} \mathrm{C},{ }^{15} \mathrm{~N} /{ }^{14} \mathrm{~N}$, and $\mathrm{D} / \mathrm{H}$ isotopic analysis explicitly indicated an interstellar origin of these biorelevant molecules [1,2,7]. Among these complex organic molecules, nicotinic acid $\left(m-\mathrm{C}_{5} \mathrm{H}_{4} \mathrm{NCOOH}\right)$ in particular has received considerable attention due to its crucial role in biological systems by serving as an important precursor to the redox coenzymes nicotinamide adenine dinucleotide (NAD) and nicotinamide adenine dinucleotide phosphate (NADP) - key components to cellular metabolic reactions [4]. Within the scope of modern metabolisms, NAD and NADP, in coordination with enzymes, promote the replication and repair of deoxyribonucleic acid (DNA), the ligation of ribonucleic acid (RNA), and cell differentiation through transfer of its nucleotidyl moiety to nucleic acids and proteins [14]. NAD has also been proposed as a potential catalyst to protometabolism on prebiotic Earth and to the origin of RNA $[15,16]$. These diverse implications of NAD in the prebiotic formation of complex, biorelevant molecules emphasize the importance of nicotinic acid in early Earth environments.

Despite the importance of nicotinic acid $\left(m-\mathrm{C}_{5} \mathrm{H}_{4} \mathrm{NCOOH}\right)$ in astrobiology and its role in the Origins of Life theme, little is known on the underlying formation pathways in extraterrestrial environments [14]. Conducting a retrosynthesis [17], the nicotinic acid molecule can be formally decomposed into a pyridine molecule $\left(\mathrm{C}_{5} \mathrm{H}_{5} \mathrm{~N}\right)$ plus carbon dioxide $\left(\mathrm{CO}_{2}\right)$. Since both molecules represent closed shell molecules in their ${ }^{1} \mathrm{~A}_{1}$ and ${ }^{1} \Sigma_{g}{ }^{+}$electronic ground states, the reaction of pyridine with carbon dioxide to form nicotinic acid in the gas phase is affiliated with a significant entrance barrier [18,19], which cannot be overcome in cold molecular clouds holding averaged translational temperatures of typically $10 \mathrm{~K}$. Further, even if formed in the gas phase via the reaction of pyridine with carbon dioxide at elevated temperatures, a third body collider is required to carry away the internal energy of the nicotinic acid prior to its unimolecular 
decomposition; however, due to the low number densities of typically $10^{-4}$ to $10^{-5} \mathrm{~cm}^{-3}$ in old molecular clouds, only bimolecular reactions take place. As a consequence, formation of nicotinic acid in the gas phase of the interstellar medium is problematic. On the other hand, complex organic molecules and carboxylic acids $(\mathrm{RCOOH})$ in particular have been shown to be formed in laboratory experiments in interstellar analog ices upon exposure of these model ices to ionizing radiation such as ultraviolet photons, galactic cosmic rays, and energetic electrons simulating the secondary electrons generated via the interaction of galactic cosmic ray particles with interstellar ices [20,21]. More specifically, formic acid (HCOOH) [22], acetic acid $\left(\mathrm{CH}_{3} \mathrm{COOH}\right)$ [17], and complex organic carboxylic acids with ' $\mathrm{R}$ ' being an organic alkyl group $(\mathrm{RCOOH})$ [21] were formed in water-carbon monoxide, methane-carbon dioxide, and carbon dioxide-hydrocarbon ices, respectively, upon exposure to energetic electrons. The initial step in the reaction was found to be the cleavage of the oxygen-hydrogen (reaction (1)) or carbonhydrogen (reaction (2) and (3)) bonds upon decomposition of water, methane, and a generic hydrocarbon, respectively. The released hydrogen atoms have excess kinetic energy of a few electron volts $(\mathrm{eV})$ and can overcome the barrier of addition to carbon monoxide (CO) of 0.12 $\mathrm{eV}$ and to carbon dioxide $\left(\mathrm{CO}_{2}\right)$ of $1.10 \mathrm{eV}$ forming the formyl (HCO) and transhydroxycarbonyl (HOCO) radical, respectively (reactions (4) and (5)). If the geometry is favorable, barrier-less radical - radical recombinations lead to the formation of formic acid (6), acetic acid (7), and alkylcarboxylic acids (8) at $10 \mathrm{~K}$ within the ices.

$$
\begin{gathered}
\mathrm{H}_{2} \mathrm{O} \rightarrow \mathrm{HO}+\mathrm{H} \\
\mathrm{CH}_{4} \rightarrow \mathrm{CH}_{3}+\mathrm{H} \\
\mathrm{RH} \rightarrow \mathrm{R}+\mathrm{H} \\
\mathrm{H}+\mathrm{CO} \rightarrow \mathrm{HCO} \\
\mathrm{H}+\mathrm{CO}_{2} \rightarrow \mathrm{HOCO} \\
\mathrm{HCO}+\mathrm{OH} \rightarrow \mathrm{HCOOH} \\
\mathrm{HOCO}+\mathrm{CH}_{3} \rightarrow \mathrm{CH}_{3} \mathrm{COOH} \\
\mathrm{HOCO}+\mathrm{R} \rightarrow \mathrm{RCOOH}
\end{gathered}
$$

In analogy to these processes, the pyridine molecule can fragment upon exposure to ionizing radiation via carbon-hydrogen loss to $o-, m$-, and $p$-pyridinyl radicals plus atomic hydrogen (reaction (9)), followed by reaction (5) with the suprathermal hydrogen atom, and recombination of the pyridinyl with the hydroxycarbonyl radical (reaction (10)). Although not yet identified in 
interstellar ices, pyridine may be formed in cold molecular clouds via the reaction of the cyano radical (CN) with 1,3-butadiene $\left(\mathrm{C}_{4} \mathrm{H}_{6}\right)$ [23,24]. During the lifetime of a molecular cloud of $10^{5}$ to $10^{6}$ years, pyridine could condense on the interstellar grains at concentrations below the detection limit of a few percent.

$$
\begin{gathered}
\mathrm{C}_{5} \mathrm{H}_{5} \mathrm{~N} \rightarrow o, m, p-\mathrm{C}_{5} \mathrm{H}_{4} \mathrm{~N}+\mathrm{H} \\
o, m, p-\mathrm{C}_{5} \mathrm{H}_{4} \mathrm{~N}+\mathrm{HOCO} \rightarrow o, m, p-\mathrm{C}_{5} \mathrm{H}_{4} \mathrm{NCOOH}
\end{gathered}
$$

Smith, et al. [25] attempted to emulate these conditions in laboratory experiments by exposing a series of pyridine-carbon dioxide and pyridine-carbon dioxide-water ices in a high vacuum chamber with pressures of a few $10^{-7}$ torr to energetic protons resulting in the formation of pyridine mono- (o-, m-, $p$-) and disubstituted (2,3-, 3,4-, and 3,5-) carboxylic acids as identified ex situ through mass spectroscopy utilizing a direct analysis in real time (DART-MS) ion source and liquid chromatography coupled with UV detection and orbitrap mass spectrometry (LCUV/MS). However, the off-line detection of the carboxylic acids raises the question if these molecules were formed within interstellar model ices and/or as a result of the hydrolysis of the extracted residues at room temperature by the solvent (water-methanol) thus making it impossible to define the source of the pyridine carboxylic acids, i.e. do these acids originate from their monomers or do they resemble hydrolysis products from the polymeric residue.

Here we explore the formation of pyridine carboxylic acids in interstellar ices analogs following irradiation with energetic electrons at $10 \mathrm{~K}$ on line and in situ. In contrast to previous studies, our experiments were conducted under contamination-free ultrahigh vacuum conditions with pressures of $10^{-11}$ torr; further, the data collection was carried out on line and in situ thus preventing contamination and hydrolysis of any residues. Furthermore, the on line studies enabled us to conduct mechanistical studies on the formation mechanism(s) of these carboxylic acids along with corresponding rate constants.

\section{EXPERIMENTAL}

The experiments were carried out in a contamination-free, ultrahigh vacuum (UHV) chamber evacuated to a pressure of $5 \times 10^{-11}$ Torr [26,27]. Desired ultrahigh vacuum conditions were achieved through the utilization of a magnetically suspended turbo-pump (Osaka TG420MCAB) backed by an oil-free scroll pump (Anest Iwata ISP-500). A highly polished silver wafer attached to an oxygen free high conductivity (OFHC) copper target interfaced to a two-stage closed-cycle 
helium refrigerator and programmable temperature controller capable of regulating temperatures between 10 and $330 \mathrm{~K}$ was placed at the center of the chamber [28]. The premixed gas mixture of pyridine-carbon dioxide was prepared by mixing 10 mbar of pyridine vapor $\left(\mathrm{C}_{5} \mathrm{H}_{5} \mathrm{~N}\right.$, Sigma Aldrich, 99.8+ \%) and 90 mbar carbon dioxide $\left(\mathrm{CO}_{2}\right.$, Airgas, $\left.99.999 \%\right)$ into an evacuated gas mixing chamber. The pyridine used for this experiment was purified by triply freezing with liquid nitrogen and evacuating the headspace, thus removing gaseous impurities such as nitrogen and oxygen. The deposition of the ice was controlled by leaking the gas mixture through a precision leak value and glass capillary array for 25 minutes at $10 \mathrm{~K}$ at a pressure of $5 \times 10^{-8}$ torr into the main chamber. The thickness of the ice was determined to be $540 \pm 80 \mathrm{~nm}$. Here, the ice thickness was determined in situ through via laser interferometry $[29,30]$ with two helium-neon (HeNe) lasers operating at $632.8 \mathrm{~nm}$. Computation of the thickness also required a value for the index of refraction for the ice mixture, to which the value for carbon dioxide $\left(n_{\mathrm{CO}_{2}}=1.245\right.$ [31]) was used based on the approximation that the ice composition closely resembled that of a pristine carbon dioxide ice. Relative abundance of the two starting materials was determined via a modified Beer-Lambert Law [26]. For carbon dioxide, the average column density was determined based on the integrated areas of $v_{1}+v_{3}$ and $2 v_{2}+v_{3}$ of $\mathrm{CO}_{2}$ and $v_{3}$ of ${ }^{13} \mathrm{CO}_{2}$, along with their corresponding absorption coefficients of $1.4 \times 10^{-18} \mathrm{~cm}$ molecule $^{-1}, 4.5 \times 10^{-19} \mathrm{~cm}$ molecule $^{-1}$, and $7.8 \times 10^{-17} \mathrm{~cm} \mathrm{molecule}^{-1}$, respectively [32]. From this, the average column density of carbon dioxide in the ice mixture is found to be $(2.64 \pm 0.08) \times 10^{17}$ molecule $\mathrm{cm}^{-2}$. After taking into account the solid density of carbon dioxide $\left(0.98 \mathrm{~g} \mathrm{~cm}^{-3}\right.$ [33]) the average thickness of the carbon dioxide component is determined to be $480 \pm 30 \mathrm{~nm}$, translating to a relative abundance of approximately $8: 1\left(\mathrm{CO}_{2} / \mathrm{C}_{5} \mathrm{H}_{5} \mathrm{~N}\right)$.

Figure 2 depicts the infrared spectrum of the deposited ice prior to the irradiation recorded with a Nicolet 6700 FTIR Spectrometer (reflection angle $\alpha=75^{\circ}$ [20]) along with vibrational assignments based upon literature values [35,36]. The assigned bands allude to the deposition of a composite ice film, with vibrations corresponding to pyridine and carbon dioxide present. Most notably, the $v_{1}+v_{3}, v_{3}$, and $v_{2}$ absorptions of carbon dioxide, present at 3750-3690, 2500-2300, and $700-650 \mathrm{~cm}^{-1}$, respectively, correspond closely to interstellar model ices studied by Bennett, et al. [36]. Likewise, evidence for C-H stretching and ring modes of pyridine are apparent in the 3100-2950 and 1370-1000 $\mathrm{cm}^{-1}$ regions, respectively, aligning with literature values of solidstate pyridine [35] (Table 1). The ice was then irradiated for 60 minutes with $5 \mathrm{keV}$ electrons at a 
current of $100 \mathrm{nA}$ from a Specs EQ 22-35 electron gun. The electron beam exposed an area of $3.2 \pm 0.3 \mathrm{~cm}^{2}$ at an angle of $15^{\circ}$ relative to the surface normal with an actual extraction efficiency of $78.8 \%$ of the electrons by scanning the beam over the ice surface. The electron trajectories and energy transfer inside the ices was modeled by the CASINO program [37]. These simulations yielded an imparted energy of $4.7 \pm 0.5 \mathrm{keV}$ per electron at an average penetration depth of $390 \pm 20 \mathrm{~nm}$ (less than the thickness of the ice to avoid interaction of the electrons with the silver wafer) translating to an average of $4.0 \pm 0.1 \mathrm{eV}$ absorbed per molecule in the deposited ice. This value corresponds to an average linear energy transfer (LET) of $12 \mathrm{keV} \mu \mathrm{m}^{-1}$, on the order of magnitude 10-20 MeV cosmic rays transfer to interstellar ices ([38,39]). The irradiated ice remained at $10 \mathrm{~K}$ for an additional 60 minutes before being heated to $293 \mathrm{~K}$ at a rate of $0.5 \mathrm{~K}$

minute $^{-1}$. In situ FTIR data were collected throughout the irradiation and temperature programmed desorption (TPD) protocol. Mass spectra (Balzers QMG 422 Quadrupole Mass Spectrometer) were collected up to a mass-to-charge ratio of $\mathrm{m} / \mathrm{z}=200$ using an electron impact ionization energy of $100 \mathrm{eV}$ at an emission current of $0.2 \mathrm{~mA}$ to monitor gaseous species released during the TPD phase $[40,41]$.

\section{RESULTS}

\section{1. Infrared Spectroscopy}

\section{1. 1. Qualitative Analysis}

Evidence for the radiation-induced formation of new species in the binary ices is apparent by novel bands present in the post-irradiation ice mixture at $10 \mathrm{~K}$. Due to the newly formed carboxylic acid species not desorbing during the TPD phase, QMS data failed to indicate the formation of these species. However, volatile reactants and light carbon species - such as carbon monoxide ( $\mathrm{CO})$ and carbon dioxide $\left(\mathrm{CO}_{2}\right)$ - were monitored to determine the temperature of desorption. The absorption features were deconvoluted exploiting Gaussian fits (Figure 3) utilizing the peak fitting application on GRAMS-AI. Details on the algorithm employed by GRAMS-AI for fittings are described in Press, et al. [42]. Peaks were iteratively fit to spectra so that the residual of the unfit portion was equivalent to the baseline noise. In situ spectra throughout the warm-up period are presented to display bands resulting from radiation products present following the sublimation of the volatile reactants. Particular interest is directed to those spectral regions associated with peaks characteristic to pyridine carboxylic acids and the 
proposed reactive intermediate, the HOCO radical. The novel absorption features along with the literature assignments are summarized in Table 2. A comprehensive summary of literature values for all pyridine carboxylic acid species along with the corresponding bands observed in this study is provided in Table 3 and Table 4.

The newly emerging bands found within the electron-irradiated ice are indicative of the formation of a variety of pyridine carboxylic acids along with the hydroxycarbonyl (HOCO) radical, carbon trioxide $\left(\mathrm{CO}_{3}\right)$, carbon monoxide $(\mathrm{CO})$ at $2141 \mathrm{~cm}^{-1}$, and ozone $\left(\mathrm{O}_{3}\right)$ at $1032 \mathrm{~cm}^{-}$ 1. We were able to identify the HOCO radical based on the absorption at $1845 \mathrm{~cm}^{-1}$ corresponding to the $v_{2}(\mathrm{CO})$ stretching mode. These assignments are in agreement with previous studies of the HOCO radical in an argon matrix at $1846 \mathrm{~cm}^{-1}$ [43] and as a byproduct of electron irradiation of interstellar model ices composed of carbon dioxide $\left(\mathrm{CO}_{2}\right)$-hydrocarbon $\left(\mathrm{C}_{n} \mathrm{H}_{2 n+2}\right.$; $n=1-6)$ and methanol $\left(\mathrm{CH}_{3} \mathrm{OH}\right)$-carbon monoxide (CO) both at $1852 \mathrm{~cm}^{-1}$ [21,41].

The processed ice at $10 \mathrm{~K}$ also displayed unambiguous evidence for the formation of the biologically relevant nicotinic acid $\left(m-\mathrm{C}_{5} \mathrm{H}_{4} \mathrm{NCOOH}\right.$ ) based on a peak at $1555 \mathrm{~cm}^{-1}$ ( $v_{8}$ [ring stretch]). This observed band agrees closely with a study completed on nicotinic acid in potassium bromide (KBr) pellets, both of which assigned $v_{8}$ at $1540 \mathrm{~cm}^{-1}$ [44]. Additionally, 2,5, 3,4-, and 3,5-pyridine dicarboxylic acid $\left(\mathrm{C}_{5} \mathrm{H}_{3} \mathrm{~N}(\mathrm{COOH})_{2}\right)$ were identified unambiguously based on their bands at $1775 \mathrm{~cm}^{-1}\left(v(\mathrm{C}=\mathrm{O})\right.$ ), $1638 \mathrm{~cm}^{-1}\left(v\left(\right.\right.$ ring)), and $1359 \mathrm{~cm}^{-1}$ ( $v_{33}$ [ring stretch]), respectively. The 2,5- and 3,4- were assigned to their respective carriers on the basis of a study conducted on the full suite of solid pyridine dicarboxylic acids in $\mathrm{KBr}$. The two aforementioned vibrations are unique to the 2,5- and 3,4- isomers, exhibiting literatures bands at $1770 \mathrm{~cm}^{-1}$ and $1640 \mathrm{~cm}^{-1}$ [45], respectively. Likewise, Nataraj, et al. [46] in the study of 3,5pyridine dicarboxylic acid in $\mathrm{KBr}$ found $v_{33}$ to occur at $1357 \mathrm{~cm}^{-1}$, matching the peak observed within this study.

In our experiments we also observed the infrared spectra of the ices throughout the heating phase. In the irradiated ice at $129 \mathrm{~K}$ we observe new bands at $1811 \mathrm{~cm}^{-1}$ and $1290 \mathrm{~cm}^{-1}$. From a previously mentioned study on pyridine dicarboxylic acids [45] we find that the band at 1811 $\mathrm{cm}^{-1}$ can be unambiguously assigned to the carrier 2,5-pyridine dicarboxylic acid due to its close resemblance with the literature value of $1790 \mathrm{~cm}^{-1}$. The same study confirms the peak at 1290 $\mathrm{cm}^{-1}$ as $\sigma(\mathrm{OH})$ of 2,3- pyridine dicarboxylic acid based on the published value of $1280 \mathrm{~cm}^{-1}$.

\section{1. 2. Quantitative Analysis}


Utilizing the peak assignments from section 3.1.1, a decrease of the column densities of the reactants, pyridine and carbon dioxide, can be computed along with the yields of the radiation products (Figure 4). For carbon dioxide, the temporal evolution of the $v_{1}+v_{3}$ and $2 v_{2}+v_{3}$ of $\mathrm{CO}_{2}$ and $v_{3}$ of ${ }^{13} \mathrm{CO}_{2}$ were monitored to determine the quantity of carbon dioxide molecules destroyed. We determined that $(3.4 \pm 0.9) \times 10^{16}$ molecule $\mathrm{cm}^{-2}$ carbon dioxide were degraded exploiting integrated absorption coefficients of $1.4 \times 10^{-18} \mathrm{~cm}$ molecule ${ }^{-1}, 4.5 \times 10^{-19} \mathrm{~cm}$ molecule $^{-1}$, and $7.8 \times 10^{-17} \mathrm{~cm}$ molecule ${ }^{-1}$ for $v_{1}+v_{3}$ and $2 v_{2}+v_{3}$ of $\mathrm{CO}_{2}$ and $v_{3}$ of ${ }^{13} \mathrm{CO}_{2}$, respectively. With the diminishing column density of carbon dioxide, new absorption features corresponding to carbon monoxide and carbon trioxide were observed. Formation of the two new carbon oxide species was monitored based on the fundamental band of carbon monoxide, present at $2141 \mathrm{~cm}^{-1}$, and the $v_{1}$ of carbon dioxide at $2044 \mathrm{~cm}^{-1}$. Bennett, et al. [26] defined the integrated absorption coefficients of the two aforementioned bands as $1.1 \times 10^{-17} \mathrm{~cm}$ molecule $^{-1}$ and $3.1 \times$ $10^{-17} \mathrm{~cm}$ molecule ${ }^{-1}$, respectively. We find that over the course of the irradiation, the total increase in column density of carbon monoxide was $(9.3 \pm 0.8) \times 10^{15}$ molecule $\mathrm{cm}^{-2}$, while the total increase of carbon trioxide was $(6.2 \pm 0.2) \times 10^{14}$ molecule $\mathrm{cm}^{-2}$. Additionally, marginal yields of the HOCO radical were recognized by the band at $1845 \mathrm{~cm}^{-1}$ corresponding to its $v_{2}$ band. Based on its integrated absorption coefficient of $3.6 \times 10^{-17} \mathrm{~cm}$ molecule $^{-1}$ [17], the column density of the HOCO radical in the irradiated ice was $(7.3 \pm 0.9) \times 10^{13}$ molecule $\mathrm{cm}^{-2}$. The total column density of newly formed carbon dioxide-based products is therefore computed to be $(1.0 \pm 0.1) \times 10^{16}$ molecule $\mathrm{cm}^{-2}$, i.e. $29 \pm 9 \%$ of the carbon dioxide was transformed into carbon trioxide, carbon monoxide, and the hydroxycarbonyl radical. We conclude that the difference between the amount of carbon dioxide destroyed and the column density of these newly formed light carbon species must be the column density of carbon dioxide molecules incorporated into pyridine carboxylic acids: $(2.4 \pm 0.9) \times 10^{16}$ molecule $\mathrm{cm}^{-2}$.

For pyridine, the change in column density is determined by monitoring the temporal development of its $v_{4}$ and $v_{11}$ bands at $755 \mathrm{~cm}^{-1}$ and $711 \mathrm{~cm}^{-1}$, respectively, using integrated absorption coefficients of $8.3 \times 10^{-19} \mathrm{~cm}$ molecule ${ }^{-1}$ and $2.4 \times 10^{-18} \mathrm{~cm}$ molecule ${ }^{-1}$. Based on the initial column density of pyridine in the pristine ice and the change in peak area of the aforementioned bands, an average of $(1.6 \pm 0.2) \times 10^{16}$ molecule $\mathrm{cm}^{-2}$ pyridine molecules were destroyed over the course of the irradiation. Since no other carriers containing the pyridine moiety were identified in the processed ice, it can be concluded that all the destroyed pyridine 
molecules were converted to pyridine carboxylic acids. Therefore, we establish the upper limit of the pyridine carboxylic acid column density of $(1.6 \pm 0.2) \times 10^{16}$ molecule $\mathrm{cm}^{-2}$. This corresponds to an overall conversion of $6 \pm 2 \%$ of the carbon dioxide reactant molecules to pyridine carboxylic acids. Completion of the mass balance for the irradiated ice involves determining the average number of carboxyl groups incorporated into each newly formed pyridine carboxylic acid. Based on the proposed reaction mechanism outlined by reactions (5), (9), and (10), it is determined the average number of carboxyl groups is equal to the column density of destroyed carbon dioxide divided by the upper limit of the carboxylic acid column density. In this manner, we find that an average of about 1.5 carbon dioxide molecules were consumed per pyridine carboxylic acid molecule formed, implying a near equal mixture of mono- and disubstituted pyridine molecules in the processed ice. These findings are consistent with the assignment of a suite of mono- and disubstituted pyridine carboxylic acid species within the irradiated ice as outlined above.

\section{DISCUSSION}

Having assigned the carriers of the newly formed molecules within the irradiated pyridinecarbon dioxide ice, we attempt now to elucidate the reaction mechanism involved in the production of the identified pyridine carboxylic acids. Similar to the mechanisms extracted in previous studies of carboxylic acid formation in interstellar model ices [21,39], the initial step in the formation of pyridine carboxylic acids in this study is the loss of a hydrogen atom, as described in reaction (9), from pyridine. This reaction is essentially a carbon-hydrogen bond cleavage and is highly endogenic by $439 \mathrm{~kJ} \mathrm{~mol}^{-1}(4.55 \mathrm{eV}$ ) for the $o$-pyridinyl radical and by $468 \mathrm{~kJ} \mathrm{~mol}^{-1}$ (4.85 eV) for the $m$ - and $p$-pyridinyl radicals [53]. The hydrogen atoms produced possess up to a few eV of kinetic energy [17,21]. Hydrogen atoms with sufficient kinetic energy are then capable of overcoming the entrance barrier of $106 \mathrm{~kJ} \mathrm{~mol}^{-1}(1.10 \mathrm{eV})$ required to form the trans-carboxyl radical (HOCO (reaction (5)). These newly formed radicals undergo radicalradical recombination without barrier with the pyridinyl radical to form a monosubstituted pyridine carboxylic acid. In an analogous process, the monosubstituted carboxylic acids can lose a second hydrogen atom from the pyridine ring via interaction with energetic electrons to form a radical and an energetic hydrogen atom. These monosubstituted pyridine carboxylic acid radicals can then recombine with a hydroxycarbonyl (HOCO) radical - if the proper recombination geometry can be reached - to form a suite of disubstituted pyridine carboxylic acids (reaction 
(11)). As nicotinic acid $\left(m-\mathrm{C}_{5} \mathrm{H}_{4} \mathrm{NCOOH}\right)$ is the only monosubstituted species unambiguously assigned, we deduce it is the primary intermediate in the formation of the observed disubstituted acids: 2,3-, 2,5-, 3,4-, and 3,5- (reaction (12)). Due to the facile conversion of the hydroxycarbonyl (HOCO) radicals to carboxylic acids, the aforementioned reaction mechanism can be formally streamlined to reactions (13-14) (Figure 5).

$$
\begin{gathered}
\mathrm{C}_{5} \mathrm{H}_{3} \mathrm{NCOOH}+\mathrm{HOCO} \rightarrow \mathrm{C}_{5} \mathrm{H}_{3} \mathrm{~N}(\mathrm{COOH})_{2} \\
m-\mathrm{C}_{5} \mathrm{H}_{3} \mathrm{NCOOH}+\mathrm{HOCO} \rightarrow 2,3-, 2,5-, 3,4-, 3,5-\mathrm{C}_{5} \mathrm{H}_{3} \mathrm{~N}(\mathrm{COOH})_{2} \\
\mathrm{C}_{5} \mathrm{H}_{5} \mathrm{~N}+\mathrm{CO}_{2} \rightarrow \mathrm{C}_{5} \mathrm{H}_{4} \mathrm{NCOOH} \\
\mathrm{C}_{5} \mathrm{H}_{4} \mathrm{NCOOH}+\mathrm{CO}_{2} \rightarrow \mathrm{C}_{5} \mathrm{H}_{3} \mathrm{~N}(\mathrm{COOH})_{2}
\end{gathered}
$$

These reaction pathways were also verified by kinetically fitting the temporal evolution of the column densities (Table 5, Figure 6). The temporal evolution of the observed pyridine carboxylic acids can be modeled by stepwise pathway A $\rightarrow$ B $\rightarrow$ C:

$$
\left[\mathrm{C}_{5} \mathrm{H}_{3} \mathrm{~N}(\mathrm{COOH})_{2}\right]_{t}=a\left(1-\frac{k_{2}}{k_{2}-k_{1}} e^{-k_{1} t}-\frac{k_{1}}{k_{2}-k_{1}} e^{-k_{2} t}\right)
$$

where $k_{1}$ is the reaction rate of reaction (13) and $k_{2}$ is the reaction rate of reaction (14). For this, the bands assigned to 2,5- and 3,4-pyridine carboxylic acids were monitored throughout the ice irradiation. Figure 6 demonstrates the best fit of the two species where $k_{1}=(4.3 \pm 2.0) \times 10^{-4} \mathrm{~s}^{-}$ ${ }^{1}$ and $k_{2}=(2.7 \pm 1.2) \times 10^{-4} \mathrm{~s}^{-1}$ for 2,5-pyridine carboxylic acid and $k_{1}=(4.5 \pm 1.7) \times 10^{-4} \mathrm{~s}^{-1}$ and $k_{2}=(2.8 \pm 1.0) \times 10^{-4} \mathrm{~s}^{-1}$ for 3,4-pyridine carboxylic acid. Collectively, we find that the addition of a single carbon dioxide molecule to pyridine proceeds forward with a rate constant of $(4.4 \pm 2.6) \times 10^{-4} \mathrm{~s}^{-1}$, while the addition of a second carbon dioxide molecule to a monosubstituted species proceeds with a lower rate constant of $(2.7 \pm 1.6) \times 10^{-4} \mathrm{~s}^{-1}$. The highly electronegative $-\mathrm{COOH}$ group likely reduces the rate of addition of a second hydroxycarbonyl radical.

As described in section 3.1.2, the temporal profiles of carbon monoxide (CO), carbon trioxide $\left(\mathrm{CO}_{3}\right)$, and ozone $\left(\mathrm{O}_{3}\right)$ were also monitored throughout the irradiation. The following formation pathways (reactions (16-19)) are +considered for the three aforementioned species:

$$
\begin{aligned}
& \mathrm{CO}_{2}\left(\mathrm{X}^{1} \Sigma_{g}^{+}\right) \rightarrow \mathrm{CO}\left(\mathrm{X}^{1} \Sigma^{-}\right)+\mathrm{O}\left({ }^{1} \mathrm{D} /{ }^{3} \mathrm{P}\right) \\
& \mathrm{CO}_{2}\left(\mathrm{X}^{1} \Sigma_{g}^{+}\right)+\mathrm{O}\left({ }^{1} \mathrm{D}\right) \rightarrow \mathrm{CO}_{3}\left(\mathrm{X}^{1} \mathrm{~A}_{1}\right) \\
& \mathrm{O}\left({ }^{3} \mathrm{P}\right)+\mathrm{O}\left({ }^{1} \mathrm{D} /{ }^{3} \mathrm{P}\right) \rightarrow \mathrm{O}_{2}\left(\mathrm{X}^{1} \Sigma_{g}^{+}\right)
\end{aligned}
$$




$$
\mathrm{O}_{2}\left(\mathrm{X}^{1} \Sigma_{g}{ }^{+}\right)+\mathrm{O}\left({ }^{1} \mathrm{D} /{ }^{3} \mathrm{P}\right) \rightarrow \mathrm{O}_{3}\left(\mathrm{X}^{1} \mathrm{~A}_{1}\right)
$$

Note that some of these reactions require intersystem crossing (ISC). Carbon dioxide is destroyed by reaction (16), producing a carbon monoxide molecule and an oxygen atom in the excited singlet state $\left({ }^{1} \mathrm{D}\right)$ and/or triplet ground state $\left({ }^{3} \mathrm{P}\right)$. This pathway is endoergic by $532 \mathrm{~kJ}$ $\mathrm{mol}^{-1}(5.51 \mathrm{eV})$ for the triplet channel and by $732 \mathrm{~kJ} \mathrm{~mol}^{-1}(7.59 \mathrm{eV})$ for the singlet channel. The energies required to complete these processes are provided by the energy deposited from energetic electrons passing through the ice mixture. Based on the electron fluence of $5.5 \times 10^{14}$ electrons $\mathrm{cm}^{-2}$, each electron initiates the destruction of $17 \pm 6$ carbon dioxide molecules, translating to $90 \pm 30 \mathrm{eV}$ electron ${ }^{-1}$ or $130 \pm 40 \mathrm{eV}$ electron $^{-1}$ for the formation of ground and excited state oxygen atoms, respectively. These suprathermal oxygen atoms react with unprocessed carbon dioxide to form carbon trioxide. Using a one step $\mathrm{A}^{\prime} \rightarrow \mathrm{B}^{\prime}$ fitting (equation (20-21)) the temporal profiles of carbon monoxide and carbon trioxide were modeled with the best fits displayed in Figure 4.

$$
\begin{aligned}
& {[\mathrm{CO}]_{t}=b\left(1-e^{-k_{3} t}\right)} \\
& {\left[\mathrm{CO}_{3}\right]_{t}=c\left(1-e^{-k_{4} t}\right)}
\end{aligned}
$$

The result of these fittings yielded $b=(3.3 \pm 0.2) \times 10^{16}$ molecules $\mathrm{cm}^{-2}$ and $c=(7.03 \pm 0.06)$ $\times 10^{15}$ molecules $\mathrm{cm}^{-2}$ along with rate constants of $k_{3}=(2.73 \pm .09) \times 10^{-3} \mathrm{~s}^{-1}$ and $k_{4}=(1.31 \pm$ $0.06) \times 10^{-4} \mathrm{~s}^{-1}$. Excess oxygen atoms produced by reaction (16) can react by the pathway described in reaction (18) to form molecular oxygen $\left(\mathrm{O}_{2}\right)$ that can subsequently react with another oxygen atom to form ozone $\left(\mathrm{O}_{3}\right)$ as in reaction (19). Both reactions can occur with either $\mathrm{O}\left({ }^{1} \mathrm{D}\right)$ or $\mathrm{O}\left({ }^{3} \mathrm{P}\right)$ since both lack of entrance barriers and are exogenic by $498.5 \mathrm{~kJ} \mathrm{~mol}^{-1}$ (5.167 $\mathrm{eV})$ and $106.5 \mathrm{~kJ} \mathrm{~mol}^{-1}(1.104 \mathrm{eV})$, respectively. Considering a consecutive $\mathrm{A}^{\prime \prime} \rightarrow \mathrm{B}^{\prime \prime} \rightarrow \mathrm{C} "$ reaction scheme, the temporal evolution was modeled by the following consecutive pseudo-first order kinetics:

$$
\left[\mathrm{O}_{3}\right]_{t}=d\left(1-\frac{k_{6}}{k_{6}-k_{5}} e^{-k_{5} t}-\frac{k_{5}}{k_{6}-k_{5}} e^{-k_{6} t}\right)
$$

where $k_{5}$ is the reaction rate of reaction (18) and $k_{6}$ is the reaction rate of reaction (19). Figure 4 shows the best fit of the ozone profile where $d=(9.2 \pm 2.8) \times 10^{14}$ molecules $\mathrm{cm}^{-2}, k_{5}=(2.4 \pm$ $0.9) \times 10^{-4} \mathrm{~s}^{-1}$ and $k_{6}=(1.5 \pm 0.6) \times 10^{-4} \mathrm{~s}^{-1}$. 


\section{Conclusion}

The present laboratory study demonstrates the formation of pyridine carboxylic acids, including the biologically relevant nicotinic acid (Vitamin B3; $m-\mathrm{C}_{5} \mathrm{H}_{4} \mathrm{NCOOH}$ ) and four dicarboxylic acids (2,3-, 2,5-, 3,4-, and 3,5-), in icy mixtures of pyridine and carbon dioxide (1:8) upon exposure to ionizing radiation in the form of energetic electrons. The carboxylic acid species unambiguously characterized within this study align closely with those identified in the Murchison [1,2] and Tagish Lake [3] meteorites, i.e. all three monosubstituted pyridine carboxylic acids. Our findings also found a similar suite of pyridine carboxylic acids as a more recent investigation on a series of CM2-type carbonaceous chondrites [4] that detected all three monosubstituted and 2,5-, 3,4-, 3,5-pyridine carboxylic acids. Additionally, our study unambiguously identified the formation of the 2,3-dicarboxylic acid species. Collectively, the array of pyridine carboxylic acids formed in the present experiment mimics the result of previous studies focusing on the irradiation of pyridine-carbon dioxide and pyridine-carbon dioxide-water ice mixtures $[4,25]$. However, unlike the aforementioned study, our experiments were conducted under contamination-free ultrahigh vacuum conditions - more characteristic of interstellar environments - with infrared data collected on line and in situ - preventing the possibility of contamination or hydrolysis of the ice by solvents (water or water-methanol) needed for DARTMS and LC-UV/MS analysis. The on line nature of our study also allowed for analysis of the temporal evolution of irradiation products as identified by the development of novel bands throughout the processing period. Underlying reaction schemes for observed products were elucidated based on optimized fittings of the collected temporal profiles. It should be noted that this study is a proof-of-concept study to probe possible formation routes of pyridine carboxylic acids and further experiments with more characteristic interstellar ices, such as those including water $\left(\mathrm{H}_{2} \mathrm{O}\right)$, are necessary.

To model the formation of pyridine carboxylic acids mechanistically, laboratory experiments completed on the formation of generic alkyl carboxylic acids ( $\mathrm{RCOOH})$ in interstellar model ices were referenced. Kim, et al. [21] postulated that carboxylic acid formation is realized in hydrocarbon-carbon dioxide ice mixtures upon exposure to energetic electrons through the hyrdoxycarbonyl (HOCO) radical intermediate formed by reactions between carbon dioxide and suprathermal hydrogen atoms lost from a hydrocarbon, R-H. The alkyl and HOCO radical may then undergo radical-radical recombination to produce carboxylic acids. In an analogous process, we propose that pyridine upon interaction with ionizing radiation may undergo hydrogen loss, 
followed by reaction of the latter with carbon dioxide leading to the formation of HOCO radical intermediates and subsequently pyridine carboxylic acids. Employing in situ infrared spectroscopy, the formation of radiation-induced mono- and disubstituted carboxylic acids was monitored along with the HOCO radical, and optimized kinetic fittings were obtained. From this, the rate constant for the addition of a single carboxyl group was determined to be (4.4 \pm 2.6$) \times$

$10^{-4} \mathrm{~s}^{-1}$, comparable to the $1.1 \times 10^{-4} \mathrm{~s}^{-1}$ found for the formation of generic alkyl carboxylic acids in hydrocarbon-carbon dioxide ice mixtures [21]. Addition of a second carbon dioxide molecule to a monosubtituted pyridine carboxylic acid was found to proceed at a rate of $(2.7 \pm 1.6) \times 10^{-4}$ $\mathrm{cm}^{2} \mathrm{~s}^{-1}$, slower than the initial addition of carbon dioxide to pyridine due to the effects of the highly electronegative carboxyl group. Evidence for the formation of disubstituted pyridine carboxylic acids, and subsequent mechanisms for their formation, compliment the recent identification of these species within carbon-rich chondrites. We can also predict that if interstellar ices contain benzene along with carbon dioxide, benzoic acid $\left(\mathrm{C}_{6} \mathrm{H}_{5} \mathrm{COOH}\right)$ should be formed based on our mechanistical data. This assertion is supported by the discovery of benzoic acid in the Murchison, Tagish Lake [54], and Orgueil meteorites [55].

\section{ACKNOWLEDGEMENTS}

These studies were supported by the RIK US National Science Foundation (AST-1505502) and the W.M. Keck Foundation. 


\section{TABLES}

Table 1.

Assignment of vibrational modes in pristine pyridine-carbon dioxide ice $\left(\mathrm{C}_{5} \mathrm{H}_{5} \mathrm{~N}-\mathrm{CO}_{2}\right)$ at $10 \mathrm{~K}$

\begin{tabular}{|c|c|c|c|}
\hline Absorption $\left(\mathrm{cm}^{-1}\right)$ & Literature Value $\left(\mathrm{cm}^{-1}\right)$ & Assignment & Characterization \\
\hline $5085,4967,4828$ & $\ldots$ & $\mathrm{CO}_{2}$ & $\begin{array}{l}\text { Combinations and } \\
\text { Overtones }\end{array}$ \\
\hline 3710 & $3700^{\mathrm{a}}$ & $v_{1}+v_{3} \mathrm{CO}_{2}$ & Combination \\
\hline 3600 & $3600^{\mathrm{a}}$ & $2 v_{2}+v_{3} \mathrm{CO}_{2}$ & Combination \\
\hline 3089 & $3087^{b}$ & $\mathrm{v}_{2} \mathrm{C}_{5} \mathrm{H}_{5} \mathrm{~N}$ & C-H Stretch \\
\hline 3062 & $3061^{b}$ & $\mathrm{v}_{13} \mathrm{C}_{5} \mathrm{H}_{5} \mathrm{~N}$ & C-H Stretch \\
\hline 3044 & $3042^{b}$ & $v_{7 b} \mathrm{C}_{5} \mathrm{H}_{5} \mathrm{~N}$ & C-H Stretch \\
\hline 3034 & $3030^{b}$ & $v_{20 \mathrm{a}} \mathrm{C}_{5} \mathrm{H}_{5} \mathrm{~N}$ & C-H Stretch \\
\hline 3009,2995 & $3010^{b}$ & $v_{8 \mathrm{a}}+v_{19 \mathrm{~b}} \mathrm{C}_{5} \mathrm{H}_{5} \mathrm{~N}$ & Combination \\
\hline 2430 & $2429^{b}$ & $v_{14}+v_{18 a} C_{5} H_{5} \mathrm{~N}$ & Combination \\
\hline 2328 & $2342^{\mathrm{a}}$ & $v_{3} \mathrm{CO}_{2}$ & Asymmetric Stretch \\
\hline 2280 & $2282^{\mathrm{a}}$ & $v_{3}{ }^{13} \mathrm{CO}_{2}$ & Asymmetric Stretch \\
\hline 2044 & $2040^{b}$ & $v_{6 a}+v_{19 b} C_{5} H_{5} N$ & Combination \\
\hline 1938 & $1925^{b}$ & $v_{9 \mathrm{a}}+v_{11} \mathrm{C}_{5} \mathrm{H}_{5} \mathrm{~N}$ & Combination \\
\hline 1639 & $1641^{b}$ & $v_{11}+v_{1} \mathrm{C}_{5} \mathrm{H}_{5} \mathrm{~N}$ & Combination \\
\hline 1603 & $1598^{b}$ & $v_{6 \mathrm{a}}+v_{1} \mathrm{C}_{5} \mathrm{H}_{5} \mathrm{~N}$ & Combination \\
\hline 1585,1574 & $1581^{b}$ & $v_{8 \mathrm{a}} \mathrm{C}_{5} \mathrm{H}_{5} \mathrm{~N}$ & Ring Stretch \\
\hline 1484 & $1483^{b}$ & $v_{19 a} \mathrm{C}_{5} \mathrm{H}_{5} \mathrm{~N}$ & Ring Stretch \\
\hline 1441 & $1442^{b}$ & $v_{19 b} \mathrm{C}_{5} \mathrm{H}_{5} \mathrm{~N}$ & Ring Stretch \\
\hline 1383 & $1384^{\mathrm{a}}$ & $2 v_{2} \mathrm{CO}_{2}$ & Overtone \\
\hline 1358 & $1362^{b}$ & $v_{14} \mathrm{C}_{5} \mathrm{H}_{5} \mathrm{~N}$ & Ring Stretch \\
\hline 1276 & $1276^{\mathrm{a}}$ & $v_{1} \mathrm{CO}_{2}$ & Symmetric Stretch \\
\hline 1147 & $1143^{b}$ & $v_{15} \mathrm{C}_{5} \mathrm{H}_{5} \mathrm{~N}$ & C-H Deform \\
\hline 1071 & $1071^{b}$ & $v_{18 \mathrm{a}} \mathrm{C}_{5} \mathrm{H}_{5} \mathrm{~N}$ & C-H Deform \\
\hline 1032 & $1032^{b}$ & $v_{12} \mathrm{C}_{5} \mathrm{H}_{5} \mathrm{~N}$ & Trigonal Ring Breathing \\
\hline 993 & $991^{b}$ & $v_{1} \mathrm{C}_{5} \mathrm{H}_{5} \mathrm{~N}$ & Ring Breathing \\
\hline 755 & $744^{b}$ & $v_{4} \mathrm{C}_{5} \mathrm{H}_{5} \mathrm{~N}$ & Ring Twist \\
\hline 711 & $700^{\mathrm{b}}$ & $v_{11} \mathrm{C}_{5} \mathrm{H}_{5} \mathrm{~N}$ & C-H Out-of-Plane Deform \\
\hline 673,655 & $667,665^{\mathrm{a}}$ & $v_{2} \mathrm{CO}_{2}$ & In-Plane/Out-of-Plane Bend \\
\hline 638 & $638^{\mathrm{a}}$ & $v_{2}{ }^{13} \mathrm{CO}_{2}$ & In-Plane/Out-of-Plane Bend \\
\hline
\end{tabular}

Notes.

${ }^{\mathrm{a}}$ Bennett, et al. [34]

${ }^{\mathrm{b}}$ Wong, et al. [35] 
Table 2.

Infrared absorption features of the irradiated pyridine-carbon dioxide ice $\left(\mathrm{C}_{5} \mathrm{H}_{5} \mathrm{~N}_{-} \mathrm{CO}_{2}\right)$ at $10 \mathrm{~K}$ and throughout heating period

\begin{tabular}{|c|c|c|c|c|c|c|c|}
\hline \multirow{2}{*}{$\begin{array}{c}\text { Absorptions } \\
\text { After Irradiation }^{\mathrm{a}} \\
10 \mathrm{~K}\end{array}$} & \multicolumn{3}{|c|}{$\begin{array}{c}\text { Absorptions During } \\
\text { Warm-Up }\end{array}$} & \multicolumn{4}{|c|}{ Literature Assignment } \\
\hline & $129 \mathrm{~K}$ & $208 \mathrm{~K}$ & $293 \mathrm{~K}$ & Wavenumber $\left(\mathrm{cm}^{-1}\right)$ & Molecule & Vibration & Characterization \\
\hline 2141 & - & - & - & $2139^{b}$ & $\mathrm{CO}$ & $v_{1}$ & Fundamental \\
\hline 2044 & - & - & - & $2041^{b}$ & $\mathrm{CO}_{3}$ & $v_{1}$ & $\mathrm{C}=\mathrm{O}$ Stretch \\
\hline 1888 & - & - & - & $1879^{\mathrm{b}}$ & $\mathrm{CO}_{3}$ & - & Fermi Resonance \\
\hline 1845 & - & - & - & $1846^{\mathrm{c}}$ & $\mathrm{HOCO}$ & $v_{2}$ & $\mathrm{C}=\mathrm{O}$ Stretch \\
\hline- & 1811 & 1804 & 1791 & $1790^{\mathrm{d}}$ & $2,5-\mathrm{C}_{5} \mathrm{H}_{3} \mathrm{~N}(\mathrm{COOH})_{2}$ & - & $\mathrm{C}=\mathrm{O}$ Stretch \\
\hline 1775 & - & - & - & $1770^{\mathrm{d}}$ & $2,5-\mathrm{C}_{5} \mathrm{H}_{3} \mathrm{~N}(\mathrm{COOH})_{2}$ & - & $\mathrm{C}=\mathrm{O}$ Stretch \\
\hline 1730 & 1722 & 1732 & 1741 & $\begin{array}{l}1730^{\mathrm{d}} \\
1730^{\mathrm{d}}\end{array}$ & $\begin{array}{l}2,4-\mathrm{C}_{5} \mathrm{H}_{3} \mathrm{~N}(\mathrm{COOH})_{2} \\
2,5-\mathrm{C}_{5} \mathrm{H}_{3} \mathrm{~N}(\mathrm{COOH})_{2}\end{array}$ & - & $\begin{array}{l}\mathrm{C}=\mathrm{O} \text { Stretch } \\
\mathrm{C}=\mathrm{O} \text { Stretch }\end{array}$ \\
\hline 1686 & 1686 & 1688 & 1693 & $\begin{array}{l}1700^{\mathrm{e}} \\
1704^{\mathrm{t}}\end{array}$ & $\begin{array}{l}2,6-\mathrm{C}_{5} \mathrm{H}_{3} \mathrm{~N}(\mathrm{COOH})_{2} \\
3,4-\mathrm{C}_{5} \mathrm{H}_{3} \mathrm{~N}(\mathrm{COOH})_{2}\end{array}$ & $\begin{array}{l}- \\
v_{6}\end{array}$ & $\begin{array}{l}\mathrm{C}=\mathrm{O} \text { Stretch } \\
\mathrm{C}=\mathrm{O} \text { Stretch }\end{array}$ \\
\hline 1638 & 1642 & 1648 & 1635 & $1640^{\mathrm{f}}$ & $3,4-\mathrm{C}_{5} \mathrm{H}_{3} \mathrm{~N}(\mathrm{COOH})_{2}$ & - & Ring Stretch \\
\hline 1605 & 1599 & 1618 & 1578 & $\begin{array}{l}1595^{\mathrm{g}, \mathrm{h}} \\
1595^{\mathrm{h}} \\
1610^{\mathrm{d}} \\
1590^{\mathrm{d}} \\
1610^{\mathrm{d}} \\
1609^{\mathrm{d}} \\
1597^{\mathrm{i}}\end{array}$ & $\begin{array}{c}o-\mathrm{C}_{5} \mathrm{H}_{4} \mathrm{NCOOH} \\
m-\mathrm{C}_{5} \mathrm{H}_{4} \mathrm{NCOOH} \\
2,3-\mathrm{C}_{5} \mathrm{H}_{3} \mathrm{~N}(\mathrm{COOH})_{2} \\
2,4-\mathrm{C}_{5} \mathrm{H}_{3} \mathrm{~N}(\mathrm{COOH})_{2} \\
2,5-\mathrm{C}_{5} \mathrm{H}_{3} \mathrm{~N}(\mathrm{COOH})_{2} \\
3,4-\mathrm{C}_{5} \mathrm{H}_{3} \mathrm{~N}(\mathrm{COOH})_{2} \\
3,5-\mathrm{C}_{5} \mathrm{H}_{3} \mathrm{~N}(\mathrm{COOH})_{2}\end{array}$ & $\begin{array}{l}v_{8 a} \\
- \\
- \\
- \\
- \\
v_{8} \\
v_{37}\end{array}$ & $\begin{array}{l}\text { Ring Stretch } \\
\text { Ring Stretch } \\
\text { Ring Stretch } \\
\text { Ring Stretch } \\
\text { Ring Stretch } \\
\text { Ring Stretch } \\
\text { Ring Stretch }\end{array}$ \\
\hline 1555 & 1548 & 1532 & 1531 & $1540^{j}$ & $m-\mathrm{C}_{5} \mathrm{H}_{4} \mathrm{NCOOH}$ & $v_{8}$ & Ring Stretch \\
\hline 1485 & 1486 & 1484 & 1487 & $\begin{array}{l}1488^{\mathrm{h}} \\
1480^{\mathrm{d}}\end{array}$ & $\begin{array}{c}m-\mathrm{C}_{5} \mathrm{H}_{4} \mathrm{NCOOH} \\
2,3-\mathrm{C}_{5} \mathrm{H}_{3} \mathrm{~N}(\mathrm{COOH})_{2}\end{array}$ & - & $\begin{array}{l}\text { Ring Stretch } \\
\text { Ring Stretch }\end{array}$ \\
\hline 1467 & 1470 & 1469 & - & $\begin{array}{c}1478^{\mathrm{h}} \\
1470^{\mathrm{d}} \\
1470,1468^{\mathrm{e}} \\
\end{array}$ & $\begin{array}{c}p-\mathrm{C}_{5} \mathrm{H}_{4} \mathrm{NCOOH} \\
2,5-\mathrm{C}_{5} \mathrm{H}_{3} \mathrm{~N}(\mathrm{COOH})_{2} \\
2,6-\mathrm{C}_{5} \mathrm{H}_{3} \mathrm{~N}(\mathrm{COOH})_{2}\end{array}$ & $\begin{array}{l}- \\
- \\
-\end{array}$ & $\begin{array}{c}\text { Ring Stretch } \\
\text { Ring Stretch } \\
\text { CH Wag, Ring Stretch }\end{array}$ \\
\hline 1441 & 1438 & 1438 & 1440 & $\begin{array}{c}1439^{\mathrm{g}, \mathrm{h}} \\
1440^{\mathrm{h}, \mathrm{j}} \\
1443^{\mathrm{i}}\end{array}$ & $\begin{array}{c}o-\mathrm{C}_{5} \mathrm{H}_{4} \mathrm{NCOOH} \\
m-\mathrm{C}_{5} \mathrm{H}_{4} \mathrm{NCOOH} \\
3,5-\mathrm{C}_{5} \mathrm{H}_{3} \mathrm{~N}(\mathrm{COOH})_{2}\end{array}$ & $\begin{array}{l}v_{19 b} \\
v_{9} \\
v_{35}\end{array}$ & $\begin{array}{l}\text { Ring Stretch } \\
\text { Ring Stretch } \\
\text { Ring Stretch }\end{array}$ \\
\hline 1359 & 1346 & 1371 & 1367 & $1357^{1}$ & $3,5-\mathrm{C}_{5} \mathrm{H}_{3} \mathrm{~N}(\mathrm{COOH})_{2}$ & $v_{33}$ & Ring Stretch \\
\hline 1317 & - & 1331 & 1323 & $\begin{array}{l}1325^{j} \\
1317^{\mathrm{f}}\end{array}$ & $\begin{array}{c}m-\mathrm{C}_{5} \mathrm{H}_{4} \mathrm{NCOOH} \\
3,4-\mathrm{C}_{5} \mathrm{H}_{3} \mathrm{~N}(\mathrm{COOH})_{2}\end{array}$ & $\begin{array}{l}v_{10} \\
v_{14}\end{array}$ & $\begin{array}{l}\text { In-Plane (COH) Def } \\
\text { Ring Stretch }\end{array}$ \\
\hline- & 1290 & 1287 & 1283 & $1280^{\mathrm{d}}$ & $2,3-\mathrm{C}_{5} \mathrm{H}_{3} \mathrm{~N}(\mathrm{COOH})_{2}$ & - & $\mathrm{OH}$ Scissor \\
\hline 1032 & 1032 & - & - & $1037^{\mathrm{K}}$ & $\mathrm{O}_{3}$ & $v_{3}$ & Asymmetric Stretch \\
\hline
\end{tabular}

Notes.

${ }^{\mathrm{a}}$ Only new absorption features and those present in ice at $298 \mathrm{~K}$ are reported as product peaks; carbon dioxide $\left(\mathrm{CO}_{2}\right)$ and other light carbon species sublimed prior to $70 \mathrm{~K}$, leaving pyridine $\left(\mathrm{C}_{5} \mathrm{H}_{5} \mathrm{~N}\right)$ and heavier radiation products; pyridine $\left(\mathrm{C}_{5} \mathrm{H}_{5} \mathrm{~N}\right)$ sublimed prior to $109 \mathrm{~K}$, leaving only heavy radiation products.

${ }^{\mathrm{b}}$ Bennett, et al. [26]

c Jacox [43]

${ }^{\mathrm{d}}$ Wasylina, et al. [45]

e Massaro, et al. [47]

${ }^{\mathrm{f}}$ Karabacak, et al. [48]

${ }^{\mathrm{g}}$ Lewandowski, et al. [49]

${ }^{\mathrm{h}}$ Koczoń, et al. [50]

${ }^{\mathrm{i}}$ Nataraj, et al. [46]

${ }^{\mathrm{j}}$ Kumar, et al. [44]

${ }^{\mathrm{k}}$ Bennett, et al. [51] 
Table 3.

Infrared absorption features of the irradiated pyridine-carbon dioxide ice $\left(\mathrm{C}_{5} \mathrm{H}_{5} \mathrm{~N}-\mathrm{CO}_{2}\right)$ at $10 \mathrm{~K}$ and throughout heating period compared to literature valukaes for mono- and disubstituted pyridine carboxylic acids

\begin{tabular}{|c|c|c|c|c|c|c|c|c|c|}
\hline \multirow{3}{*}{$\begin{array}{c}\text { Experimental } \\
\text { Absorptions }\left(\mathrm{cm}^{-1}\right)^{\mathrm{a}} \\
10 \mathrm{~K}\end{array}$} & \multicolumn{7}{|c|}{ Literature Values $\left(\mathrm{cm}^{-1}\right)$} & & \\
\hline & \multicolumn{3}{|c|}{ Monosubstituted } & \multicolumn{6}{|c|}{ Disubstituted } \\
\hline & Ortho- $^{\text {b,c }}$ & Meta- $^{\mathrm{c}, \mathrm{d}}$ & Para- $^{\mathrm{C}}$ & $2,3-^{e}$ & $2,4^{-}{ }^{\mathrm{e}}$ & $2,5^{-}{ }^{e}$ & $2,6-{ }^{f}$ & $3,4^{e, g}$ & $3,5^{-h}$ \\
\hline $1811-1790$ & $\ldots$ & $\ldots$ & $\ldots$ & $\ldots$ & $\ldots$ & 1790 & $\ldots$ & $\ldots$ & $\ldots$ \\
\hline 1775 & $\ldots$ & $\ldots$ & $\ldots$ & $\ldots$ & $\ldots$ & 1770 & $\ldots$ & $\ldots$ & $\ldots$ \\
\hline $1741-1722$ & $\ldots$ & $\ldots$ & $\ldots$ & $\ldots$ & 1730 & 1730 & $\ldots$ & $\ldots$ & $\ldots$ \\
\hline$\cdots$ & 1717 & $\begin{array}{l}1711 \\
1708 \\
\end{array}$ & 1712 & $\cdots$ & $\cdots$ & $\cdots$ & 1710 & 1704 & $\cdots$ \\
\hline $1693-1686$ & $\ldots$ & $\ldots$ & $\ldots$ & $\ldots$ & $\ldots$ & $\ldots$ & 1700 & $\ldots$ & $\ldots$ \\
\hline $1648-1635$ & $\ldots$ & $\ldots$ & $\ldots$ & $\ldots$ & $\ldots$ & $\ldots$ & $\ldots$ & 1640 & $\ldots$ \\
\hline$\ldots$ & 1608 & $\ldots$ & $\ldots$ & $\ldots$ & $\ldots$ & $\ldots$ & $\ldots$ & $\ldots$ & $\ldots$ \\
\hline $1618-1578$ & 1595 & $\begin{array}{l}1595 \\
1583\end{array}$ & $\begin{array}{l}1616 \\
1597\end{array}$ & $\begin{array}{l}1610 \\
1580\end{array}$ & 1590 & 1610 & 1576 & 1609 & 1597 \\
\hline$\ldots$ & 1573 & $\ldots$ & $\ldots$ & $\ldots$ & $\ldots$ & $\ldots$ & 1571 & $\ldots$ & $\ldots$ \\
\hline $1548-1531$ & $\ldots$ & 1540 & $\ldots$ & $\ldots$ & $\ldots$ & $\ldots$ & $\ldots$ & $\ldots$ & $\ldots$ \\
\hline$\ldots$ & $\ldots$ & $\ldots$ & $\ldots$ & $\ldots$ & 1500 & $\ldots$ & $\ldots$ & $\ldots$ & $\ldots$ \\
\hline $1487-1484$ & $\ldots$ & 1488 & $\ldots$ & 1480 & $\ldots$ & $\ldots$ & $\ldots$ & $\ldots$ & $\ldots$ \\
\hline$\ldots$ & $\ldots$ & $\ldots$ & 1478 & $\ldots$ & $\ldots$ & $\ldots$ & $\ldots$ & $\ldots$ & $\ldots$ \\
\hline $1470-1467$ & $\cdots$ & $\cdots$ & $\cdots$ & $\cdots$ & $\cdots$ & 1470 & $\begin{array}{l}1470 \\
1468 \\
\end{array}$ & $\cdots$ & $\cdots$ \\
\hline$\ldots$ & 1455 & $\ldots$ & $\ldots$ & $\ldots$ & $\ldots$ & $\ldots$ & $\ldots$ & $\ldots$ & $\ldots$ \\
\hline $1441-1438$ & 1439 & 1440 & $\ldots$ & $\ldots$ & $\ldots$ & $\ldots$ & $\ldots$ & $\ldots$ & 1443 \\
\hline$\cdots$ & $\ldots$ & 1407 & 1412 & $\begin{array}{l}1430 \\
1420 \\
\end{array}$ & 1390 & $\begin{array}{l}1420 \\
1400 \\
\end{array}$ & $\begin{array}{l}1422 \\
1387 \\
\end{array}$ & 1405 & 1383 \\
\hline $1371-1346$ & $\ldots$ & $\ldots$ & $\ldots$ & $\ldots$ & $\ldots$ & $\ldots$ & $\ldots$ & $\ldots$ & 1357 \\
\hline$\ldots$ & $\ldots$ & $\ldots$ & $\ldots$ & $\ldots$ & $\ldots$ & $\ldots$ & 1341 & $\ldots$ & $\ldots$ \\
\hline $1331-1317$ & $\ldots$ & 1325 & $\ldots$ & $\ldots$ & $\ldots$ & $\ldots$ & $\ldots$ & 1317 & $\ldots$ \\
\hline$\ldots$ & $\ldots$ & $\ldots$ & $\ldots$ & 1310 & 1310 & $\ldots$ & 1308 & $\ldots$ & 1298 \\
\hline $1290-1283$ & $\ldots$ & $\ldots$ & $\ldots$ & 1280 & $\ldots$ & $\ldots$ & $\ldots$ & $\ldots$ & $\ldots$ \\
\hline
\end{tabular}

Notes.

${ }^{a}$ Range of wavenumbers indicates the shift in the assigned band between the irradiated sample at $10 \mathrm{~K}$ and during the warm-up.

${ }^{\mathrm{b}}$ Lewandowski, et al. [49]

c Koczoń, et al. [50]

${ }^{\mathrm{d}}$ Kumar, et al. [52]

e Wasylina, et al. [45]

f Massaro, et al. [47]

${ }^{\mathrm{g}}$ Karabacak, et al. [48]

${ }^{\mathrm{h}}$ Nataraj, et al. [46] 
Table 4.

Compilation of new molecules formed in pyridine-carbon dioxide ice $\left(\mathrm{C}_{5} \mathrm{H}_{5} \mathrm{~N}-\mathrm{CO}_{2}\right)$ at $10 \mathrm{~K}$ and throughout heating period

\begin{tabular}{|c|c|c|c|}
\hline Molecule & Absorption $\left(\mathrm{cm}^{-1}\right)^{\mathrm{a}}$ & " Literature Value $\left(\mathrm{cm}^{-1}\right)$ & Assignment \\
\hline \multirow[t]{2}{*}{$O-\mathrm{C}_{5} \mathrm{H}_{4} \mathrm{NCOOH}$} & $1618-1578$ & $1595^{\mathrm{b}, \mathrm{c}}$ & $v_{8 a}$ \\
\hline & $1441-1438$ & $1439^{\mathrm{b}, \mathrm{c}}$ & $v_{19 \mathrm{~b}}$ \\
\hline \multirow[t]{5}{*}{$m-\mathrm{C}_{5} \mathrm{H}_{4} \mathrm{NCOOH}$} & $1618-1578$ & $1595,1583^{\mathrm{c,d}}$ & $v($ ring) \\
\hline & $1548-1531$ & $1540^{\mathrm{d}}$ & $v_{8}$ \\
\hline & $1487-1484$ & $1488^{\mathrm{d}}$ & $v$ (ring) \\
\hline & $1441-1438$ & $1440^{\mathrm{c}, \mathrm{d}}$ & $v_{9}$ \\
\hline & $1331-1317$ & $1325^{\mathrm{d}}$ & $v_{10}$ \\
\hline$p-\mathrm{C}_{5} \mathrm{H}_{4} \mathrm{NCOOH}$ & $1618-1578$ & $1616,1597^{\mathrm{C}}$ & $v($ ring) \\
\hline \multirow{3}{*}{$2,3-\mathrm{C}_{5} \mathrm{H}_{3} \mathrm{~N}(\mathrm{COOH})_{2}$} & $1618-1578$ & $1610,1580^{\mathrm{e}}$ & $v$ (ring) \\
\hline & $1487-1484$ & $1480^{\mathrm{e}}$ & $v$ (ring) \\
\hline & $1290-1283$ & $1280^{\mathrm{e}}$ & $\sigma(\mathrm{OH})$ \\
\hline \multirow{2}{*}{$2,4-\mathrm{C}_{5} \mathrm{H}_{3} \mathrm{~N}(\mathrm{COOH})_{2}$} & $1741-1722$ & $1730^{\mathrm{e}}$ & $v(\mathrm{C}=\mathrm{O})$ \\
\hline & $1618-1578$ & $1590^{\mathrm{e}}$ & $v$ (ring) \\
\hline \multirow[t]{5}{*}{$2,5-\mathrm{C}_{5} \mathrm{H}_{3} \mathrm{~N}(\mathrm{COOH})_{2}$} & $1811-1790$ & $1790^{\mathrm{e}}$ & $v(\mathrm{C}=\mathrm{O})$ \\
\hline & 1775 & $1770^{\mathrm{e}}$ & $v(\mathrm{C}=\mathrm{O})$ \\
\hline & $1741-1722$ & $1730^{\mathrm{e}}$ & $v(\mathrm{C}=\mathrm{O})$ \\
\hline & $1618-1578$ & $1610^{\mathrm{e}}$ & $v($ ring) \\
\hline & $1470-1467$ & $1470^{\mathrm{e}}$ & $v$ (ring) \\
\hline \multirow[t]{3}{*}{$2,6-\mathrm{C}_{5} \mathrm{H}_{3} \mathrm{~N}(\mathrm{COOH})_{2}$} & $1693-1686$ & $1700^{f}$ & $v(\mathrm{C}=\mathrm{O})$ \\
\hline & $1618-1578$ & $1576^{\mathrm{t}}$ & $v$ (ring) \\
\hline & $1470-1467$ & $1470,1468^{\mathrm{f}}$ & $\rho(\mathrm{CH}), v(\mathrm{C}-\mathrm{N})$ \\
\hline \multirow[t]{4}{*}{$3,4-\mathrm{C}_{5} \mathrm{H}_{3} \mathrm{~N}(\mathrm{COOH})_{2}$} & $1693-1686$ & $1704^{\mathrm{g}}$ & $v_{6}$ \\
\hline & $1648-1635$ & $1640^{\mathrm{g}}$ & $v$ (ring) \\
\hline & $1618-1578$ & $1609^{g}$ & $v_{8}$ \\
\hline & $1331-1317$ & $1317^{\mathrm{g}}$ & $v_{14}$ \\
\hline \multirow[t]{3}{*}{$3,5-\mathrm{C}_{5} \mathrm{H}_{3} \mathrm{~N}(\mathrm{COOH})_{2}$} & $1618-1578$ & $1597^{\mathrm{h}}$ & $v_{37}$ \\
\hline & $1441-1438$ & $1443^{\mathrm{h}}$ & $v_{35}$ \\
\hline & $1371-1346$ & $1357^{\mathrm{h}}$ & $v_{33}$ \\
\hline
\end{tabular}

Notes.

${ }^{\text {a }}$ Range of wavenumbers indicates the shift in the assigned band between the irradiated sample at

$10 \mathrm{~K}$ and during the warm-up.

${ }^{\mathrm{b}}$ Lewandowski, et al. [49]

${ }^{\text {c } K o c z o n ́, ~ e t ~ a l . ~[50] ~}$

${ }^{d}$ Kumar, et al. [44]

e Wasylina, et al. [45]

${ }^{\mathrm{f}}$ Massaro, et al. [47]

${ }^{g}$ Karabacak, et al. [48]

${ }^{\mathrm{h}}$ Nataraj, et al. [46] 
Table 5.

Rate constants and production yields of proposed reactions and new products in pyridine-carbon dioxide ice $\left(\mathrm{C}_{5} \mathrm{H}_{5} \mathrm{~N}-\mathrm{CO}_{2}\right)$

\begin{tabular}{ccc}
\hline \hline Reactions & $\begin{array}{c}\text { Column Density } \\
\left(\text { molecules cm } \mathrm{cm}^{-2}\right)\end{array}$ & $\begin{array}{c}\text { Rate Constant } \\
\left(\mathrm{s}^{-1}\right)\end{array}$ \\
\hline $\mathrm{CO}_{2} \rightarrow \mathrm{CO}+\mathrm{O}$ & $(9.3 \pm 0.8) \times 10^{15}$ & $(2.73 \pm 0.09) \times 10^{-3}$ \\
$\mathrm{CO}_{2}+\mathrm{O} \rightarrow \mathrm{CO}_{3}$ & $(6.2 \pm 0.2) \times 10^{14}$ & $(1.31 \pm 0.06) \times 10^{-4}$ \\
$\mathrm{CO}_{2}+\mathrm{H} \rightarrow \mathrm{HOCO}^{\mathrm{O}}+\mathrm{O} \rightarrow \mathrm{O}_{2}$ & $(7.3 \pm 0.9) \times 10^{13}$ & $\ldots$ \\
$\mathrm{O}_{2}+\mathrm{O} \rightarrow \mathrm{O}_{3}$ & $\ldots$ & $(2.4 \pm 0.9) \times 10^{-4}$ \\
$\mathrm{C}_{5} \mathrm{H}_{5} \mathrm{~N}+\mathrm{CO}_{2} \rightarrow \mathrm{C}_{5} \mathrm{H}_{4} \mathrm{~N}(\mathrm{COOH})$ & $(9.2 \pm 2.8) \times 10^{14}$ & $(1.5 \pm 0.6) \times 10^{-4}$ \\
$\mathrm{C}_{5} \mathrm{H}_{4} \mathrm{~N}(\mathrm{COOH})+\mathrm{CO}_{2} \rightarrow \mathrm{C}_{5} \mathrm{H}_{4} \mathrm{~N}(\mathrm{COOH})_{2}$ & $\ldots$ & $(4.4 \pm 2.6) \times 10^{-4}$ \\
\hline
\end{tabular}




\section{FIGURE CAPTIONS}

Figure 1. Nine mono- and disubstituted pyridine carboxylic acid species. Of particular interest is nicotinic acid $(\mathrm{m}$ $\mathrm{C}_{5} \mathrm{H}_{4} \mathrm{NCOOH}$; top, center) due to its biological significance in terrestrial environments. In addition to the full suite of monosubstituted pyridine carboxylic acids (top), 2,5- (middle, right), 3,4- (bottom, center), and 3,5- (bottom, right) disubsituted pyridine carboxylic acids have recently been identified within a series of CM2-type carbonaceous chondrites.

Figure 2. Mid-infrared spectra of the solid $10 \%$ pyridine $\left(\mathrm{C}_{5} \mathrm{H}_{5} \mathrm{~N}\right)$ in carbon dioxide $\left(\mathrm{CO}_{2}\right)$ ice before the irradiation at $10 \mathrm{~K}$ (black). The top left spectrum displays the full spectral range of 6000 to $500 \mathrm{~cm}^{-1}$ with the irradiated ice shown in red. The remaining three panels depict zoomed in regions of the full spectrum. The assignment of peaks corresponding to the two starting materials is displayed on each graph.

Figure 3. Deconvoluted infrared spectrum of ice following irradiation with energetic electrons at $10 \mathrm{~K}, 129 \mathrm{~K}, 208$ $\mathrm{K}$, and $293 \mathrm{~K}$ (from top to bottom). The two regions in which relevant bands were found, 3350-2950 $\mathrm{cm}^{-1}$ (left) and $1950-1400 \mathrm{~cm}^{-1}$ (right), are displayed. The red lines correspond to experimentally collected infrared spectra, the black lines correspond to deconvoluted fits of structures within the ice, and the blue line corresponds to the sum of the deconvoluted fittings. Absorption features assigned to radiation products are labeled by wavenumber.

Figure 4. Fit of temporal (integrated IR absorption) evolution of the two starting materials pyridine $\left(\mathrm{C}_{5} \mathrm{H}_{5} \mathrm{~N}\right)$ and carbon dioxide $\left(\mathrm{CO}_{2}\right)$, and the newly formed light irradiation products carbon monoxide (CO), carbon trioxide $\left(\mathrm{CO}_{3}\right)$, and ozone $\left(\mathrm{O}_{3}\right)$ throughout the 1-hour irradiation period.

Figure 5. Reaction scheme used to fit the temporal evolution of the identified pyridine carboxylic acids.

Figure 6. Fit of temporal (normalized integrated IR absorption) evolution of 2,5- and 3,4-pyridine carboxylic acid throughout the 1-hour irradiation period. The profiles were fit based on a pseudo first-order, consecutive $\mathrm{A} \rightarrow \mathrm{B} \rightarrow \mathrm{C}$ reaction scheme. 


\section{REFERENCES}

[1] S. Pizzarello, Y. Huang, M. Fuller, Geochimica et Cosmochimica Acta 68 (2004) 4963.

[2] S. Pizzarello, Y. Huang, Geochimica et Cosmochimica Acta 69 (2005) 599.

[3] S. Pizzarello, Y. Huang, L. Becker, R.J. Poreda, R.A. Nieman, G. Cooper, M. Williams, Science 293 (2001) 2236.

[4] K.E. Smith, M.P. Callahan, P.A. Gerakines, J.P. Dworkin, C.H. House, Geochimica et Cosmochimica Acta 136 (2014) 1.

[5] P. Schmitt-Kopplin, Z. Gabelica, R.D. Gougeon, A. Fekete, B. Kanawati, M. Harir, I. Gebefuegi, G. Eckel, N. Hertkorn, Proceedings of the National Academy of Sciences 107 (2010) 2763.

[6] W. Meinschein, Nature 197 (1963) 833.

[7] M.A. Sephton, Natural Product Reports 19 (2002) 292.

[8] M.P. Callahan, K.E. Smith, H.J. Cleaves, J. Ruzicka, J.C. Stern, D.P. Glavin, C.H. House, J.P. Dworkin, Proceedings of the National Academy of Sciences 108 (2011) 13995.

[9] G. Cooper, N. Kimmich, W. Belisle, J. Sarinana, K. Brabham, L. Garrel, Nature 414 (2001) 879.

[10] R.I. Kaiser, S. Maity, B.M. Jones, Angew Chem Int Edit 54 (2015) 195.

[11] S.B. Charnley, P. Ehrenfreund, Y.J. Kuan, Spectrochimica Acta Part A: Molecular and Biomolecular Spectroscopy 57 (2001) 685.

[12] R.I. Kaiser, A.M. Stockton, Y.S. Kim, E.C. Jensen, R.A. Mathies, Astrophys J 765 (2013) 111.

[13] K. Kvenvolden, J. Lawless, K. Pering, E. Peterson, J. Flores, C. Ponnamperuma, I. Kaplan, C. Moore, Nature 228 (1970) 928.

[14] N. Raffaelli, Origins of Life: The Primal Self-Organization, Springer, 2011, p. 185.

[15] H.J. Cleaves, S.L. Miller, Journal of molecular evolution 52 (2001) 73.

[16] S.D. Copley, E. Smith, H.J. Morowitz, Bioorganic chemistry 35 (2007) 430.

[17] C.J. Bennett, R.I. Kaiser, The Astrophysical Journal 660 (2007) 1289.

[18] R.T. Garrod, E. Herbst, Astron Astrophys 457 (2006) 927.

[19] R.T. Garrod, S.L.W. Weaver, E. Herbst, The Astrophysical Journal 682 (2008) 283.

[20] C.J. Bennett, S.-H. Chen, B.-J. Sun, A.H.H. Chang, R.I. Kaiser, The Astrophysical Journal 660 (2007) 1588.

[21] Y.S. Kim, R.I. Kaiser, The Astrophysical Journal 725 (2010) 1002.

[22] C.J. Bennett, T. Hama, Y.S. Kim, M. Kawasaki, R.I. Kaiser, The Astrophysical Journal 727 (2011) 27.

[23] B.J. Sun, C.H. Huang, S.Y. Chen, S.H. Chen, R.I. Kaiser, A.H.H. Chang, J Phys Chem A 118 (2014) 7715.

[24] S.B. Morales, C.J. Bennett, S.D. Le Picard, A. Canosa, I.R. Sims, B. Sun, P. Chen, A.H. Chang, V.V. Kislov, A.M. Mebel, The Astrophysical Journal 742 (2011) 26.

[25] K.E. Smith, P.A. Gerakines, M.P. Callahan, Chemical Communications 51 (2015) 11787.

[26] C.J. Bennett, C. Jamieson, A.M. Mebel, R.I. Kaiser, Physical Chemistry Chemical Physics 6 (2004) 735.

[27] R.I. Kaiser, G. Eich, A. Gabrysch, K. Roessler, The Astrophysical Journal 484 (1997) 487.

[28] W. Zheng, D. Jewitt, R.I. Kaiser, The Astrophysical Journal 639 (2006) 534. 
[29] O.S. Heavens, Optical Properties of Thin Solid Films, Butterworhts Scientific Publications, London, 1955.

[30] L. Zhou, S. Maity, M. Abplanalp, A. Turner, R.I. Kaiser, The Astrophysical Journal 790 (2014) 38.

[31] G. Baratta, M. Palumbo, JOSA A 15 (1998) 3076.

[32] P.A. Gerakines, W.A. Schutte, J.M. Greenberg, E.F. Van Dishoeck, Astronomy and Astrophysics 296 (1995) 810.

[33] M. Satorre, M. Domingo, C. Millán, R. Luna, R. Vilaplana, C. Santonja, Planetary and Space Science 56 (2008) 1748.

[34] C.J. Bennett, C.S. Jamieson, R.I. Kaiser, Physical Chemistry Chemical Physics 12 (2010) 4032.

[35] K.N. Wong, S.D. Colson, Journal of Molecular Spectroscopy 104 (1984) 129.

[36] C.J. Bennett, C. Jamieson, S., R. Kaiser, I., The Astrophysical Journal Supplement Series 182 (2009) 1.

[37] D. Drouin, A.R. Couture, D. Joly, X. Tastet, V. Aimez, R. Gauvin, Scanning 29 (2007) 92.

[38] Y. Kim, R. Kaiser, The Astrophysical Journal 725 (2010) 1002.

[39] C.J. Bennett, C.S. Jamieson, Y. Osamura, R.I. Kaiser, The Astrophysical Journal 624 (2005) 1097.

[40] R.I. Kaiser, P. Maksyutenko, C. Ennis, F. Zhang, X. Gu, S.P. Krishtal, A.M. Mebel, O. Kostko, M. Ahmed, Faraday discussions 147 (2010) 429.

[41] C.J. Bennett, R.I. Kaiser, The Astrophysical Journal 661 (2007) 899.

[42] W.H. Press, B. Flannery, S. Teukolsky, W. Vetterling, London: Cambridge University, 1986, p. 521.

[43] M.E. Jacox, The Journal of Chemical Physics 88 (1988) 4598.

[44] M. Kumar, R. Yadav, Spectrochimica Acta Part A: Molecular and Biomolecular Spectroscopy 79 (2011) 1316.

[45] L. Wasylina, E. Kucharska, Z. Weglinski, A. Puszko, Chemistry of Heterocyclic Compounds 35 (1999) 186.

[46] A. Nataraj, V. Balachandran, T. Karthick, M. Karabacak, A. Atac, Journal of Molecular Structure 1027 (2012) 1.

[47] R.D. Massaro, E. Blaisten-Barojas, Computational and Theoretical Chemistry 977 (2011) 148.

[48] M. Karabacak, S. Bilgili, A. Atac, Spectrochimica Acta Part A: Molecular and Biomolecular Spectroscopy 135 (2015) 270.

[49] W. Lewandowski, G. Świderski, R. Świslocka, S. Wojtulewski, P. Koczoń, Journal of physical organic chemistry 18 (2005) 918.

[50] P. Koczoń, J.C. Dobrowolski, W. Lewandowski, A. Mazurek, Journal of molecular structure 655 (2003) 89.

[51] C.J. Bennett, R.I. Kaiser, The Astrophysical Journal 635 (2005) 1362.

[52] M. Kumar, M. Srivastava, R.A. Yadav, Spectrochimica Acta Part A: Molecular and Biomolecular Spectroscopy 111 (2013) 242.

[53] Y.-R. Luo, Handbook of bond dissociation energies in organic compounds, CRC press, 2002.

[54] Z. Martins, J. Watson, M. Sephton, O. Botta, P. Ehrenfreund, I. Gilmour, Meteoritics \& Planetary Science 41 (2006) 1073. 
[55] Y. Huang, Y. Wang, M.R. Alexandre, T. Lee, C. Rose-Petruck, M. Fuller, S. Pizzarello, Geochimica et Cosmochimica Acta 69 (2005) 1073. 
Figure 1
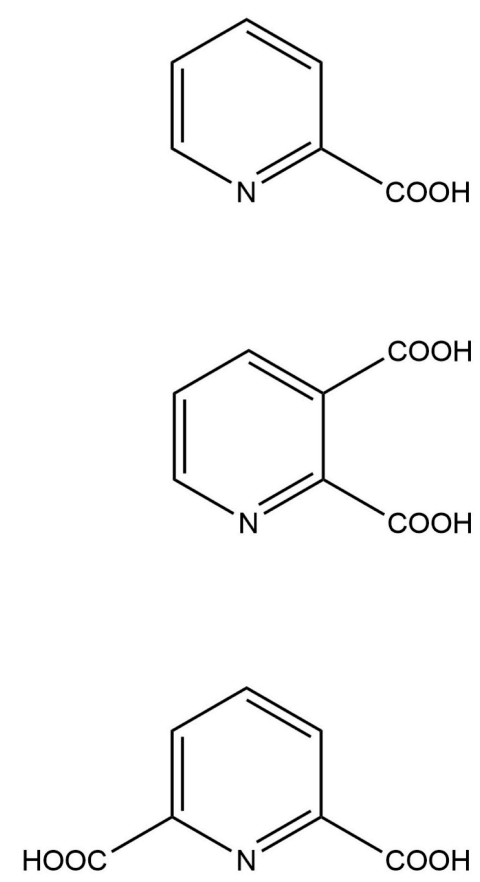
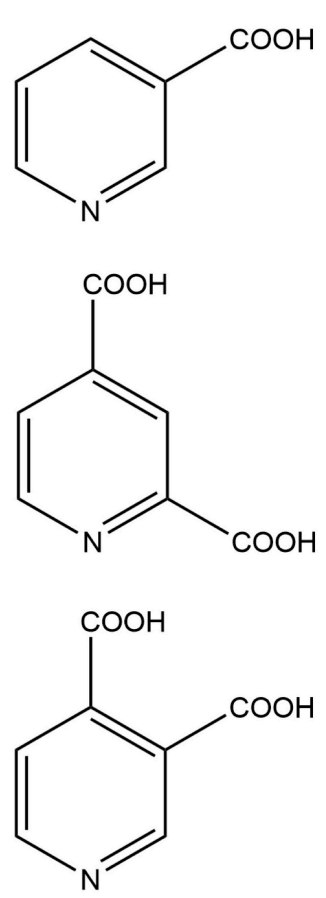

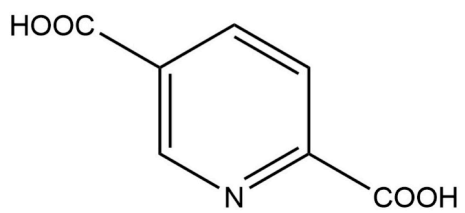<smiles>O=C(O)c1ccncc1</smiles><smiles>O=C(O)c1cncc(C(=O)O)c1</smiles> 
Figure 2
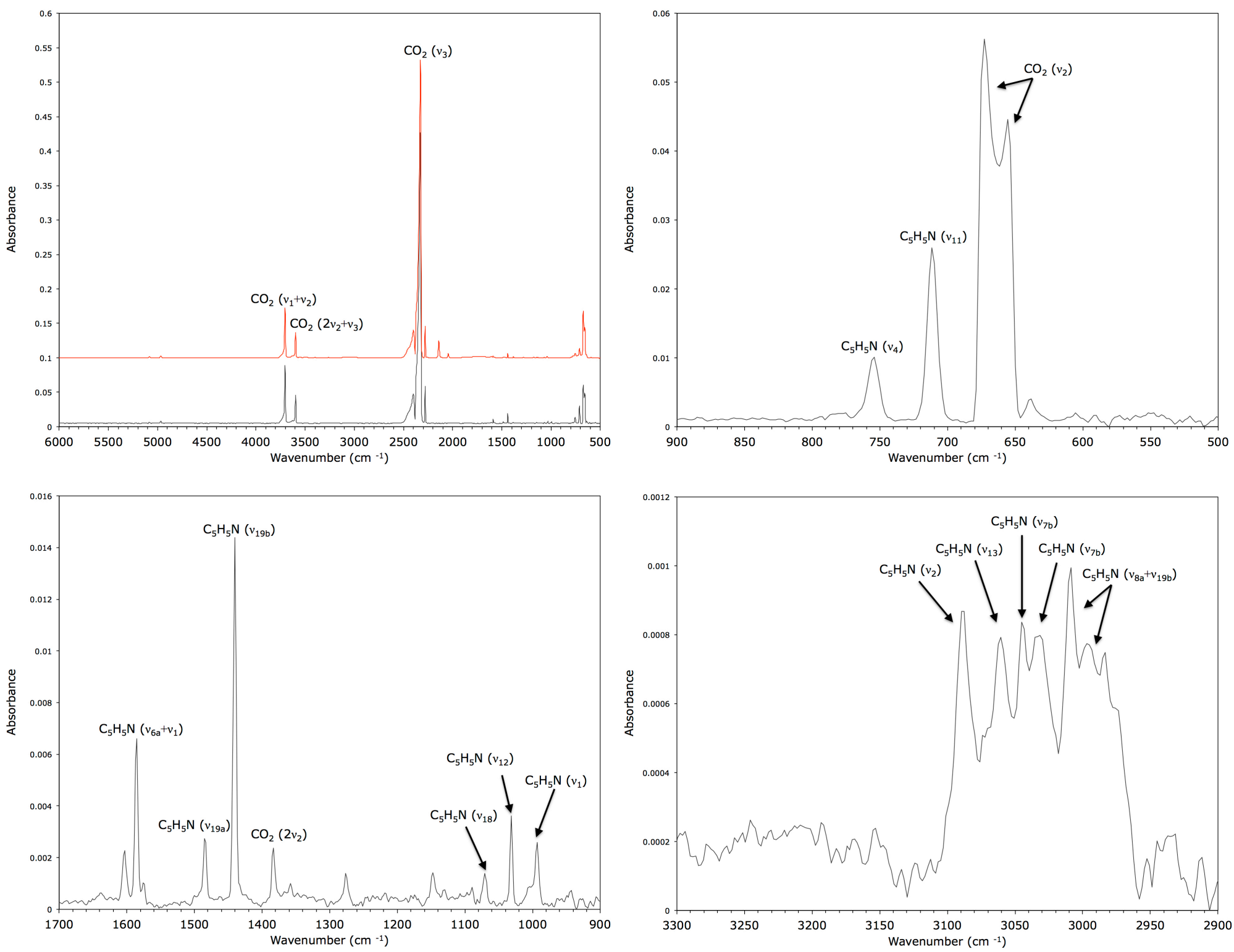
Figure 3
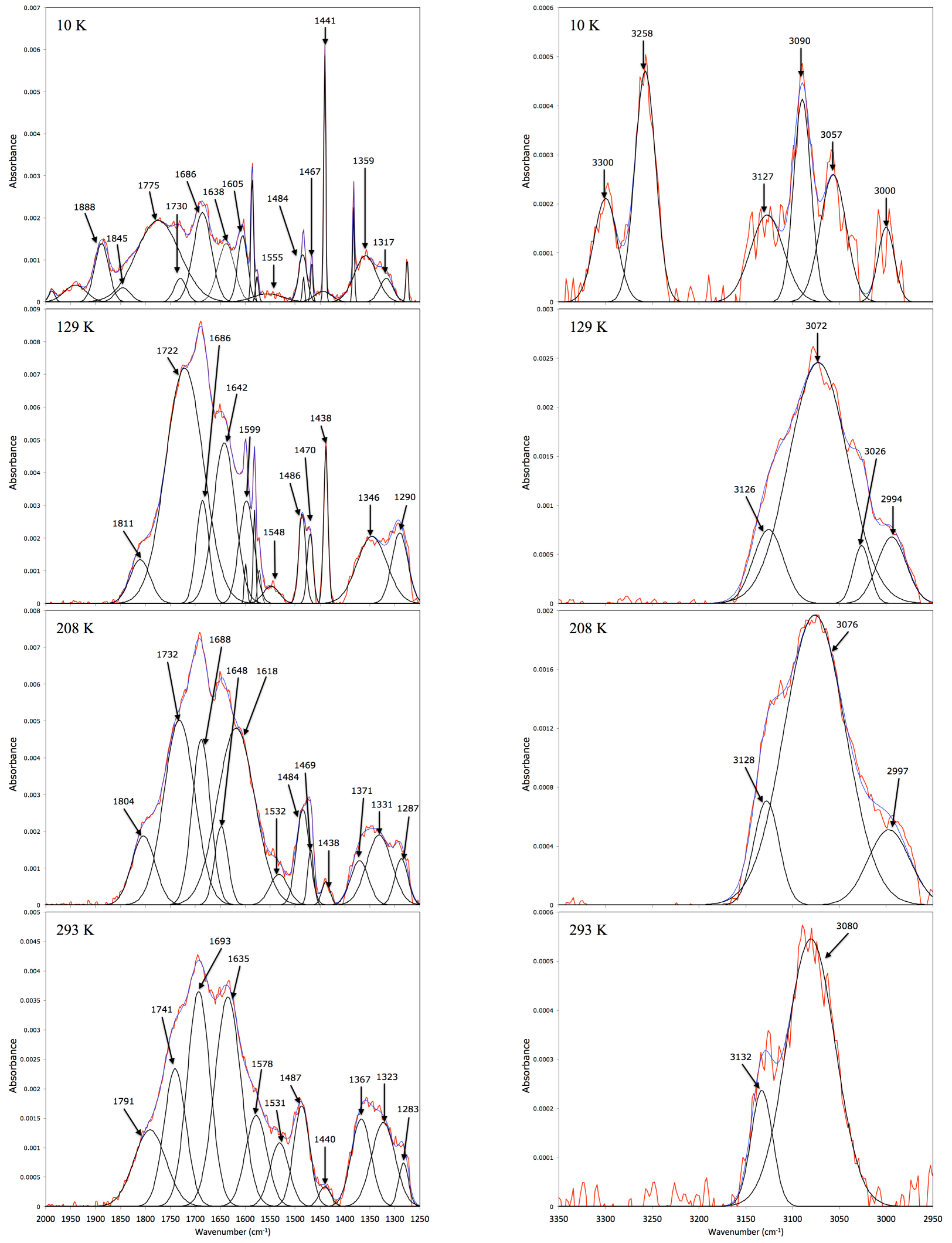
Figure 4
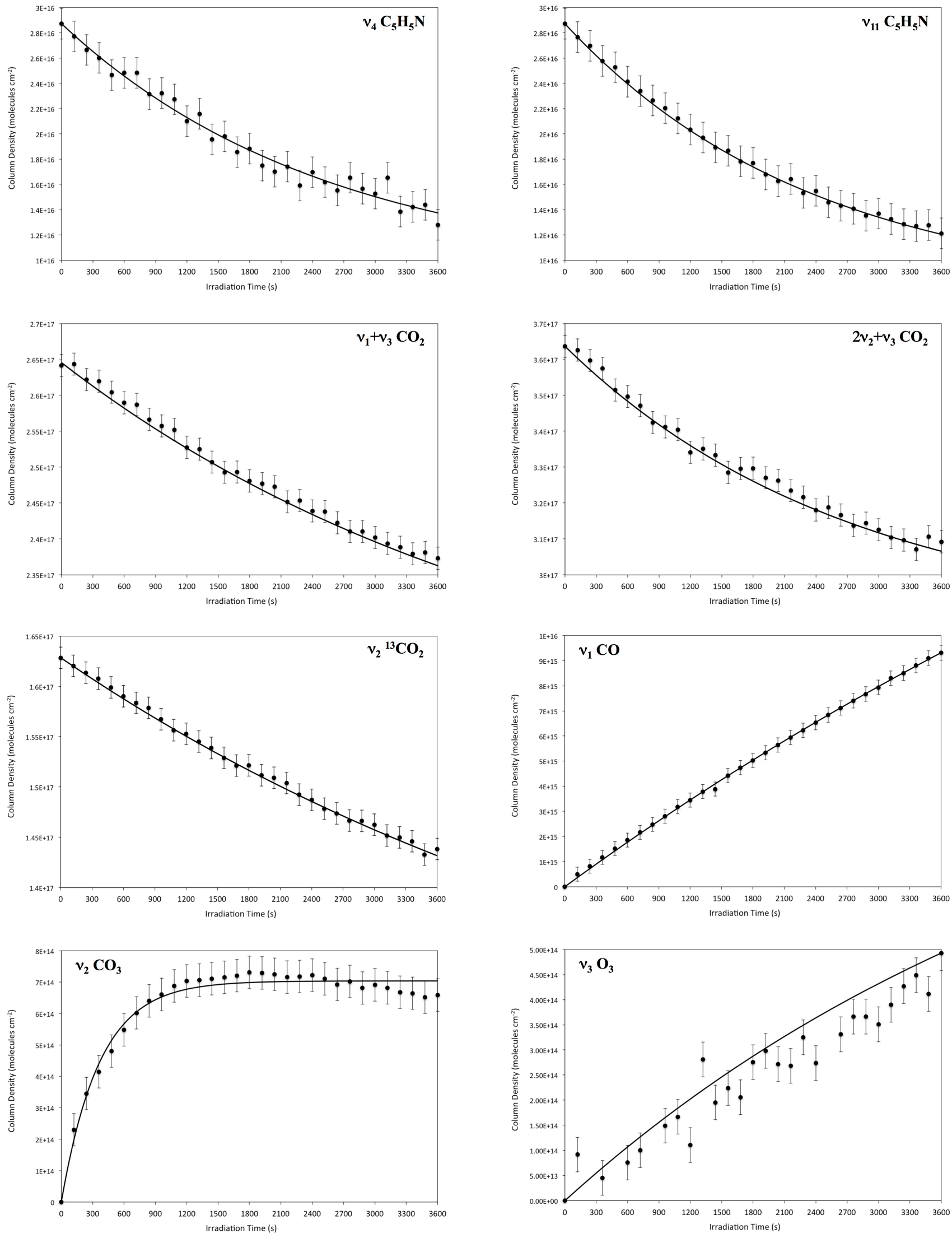
Figure 5

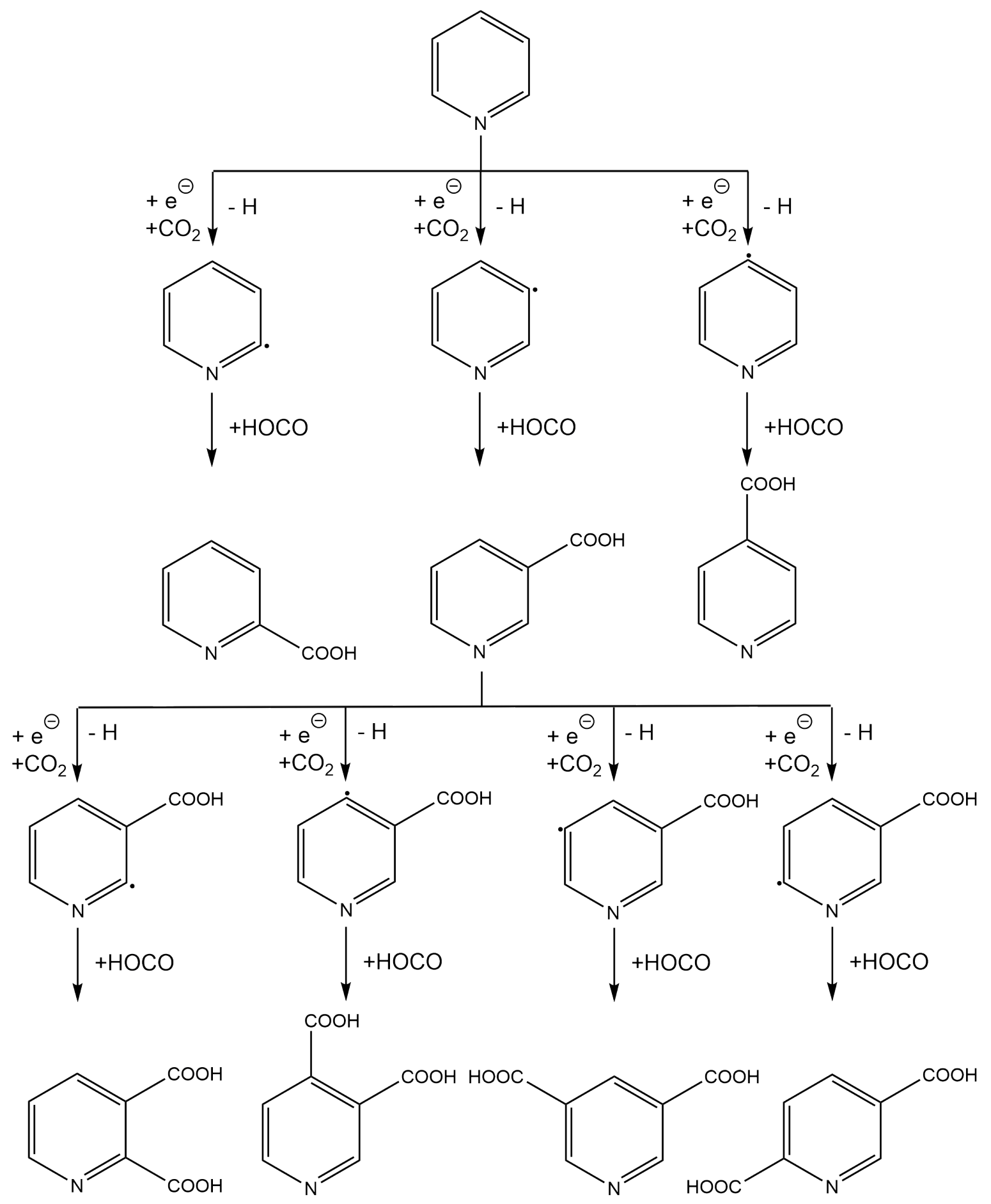


Figure 6
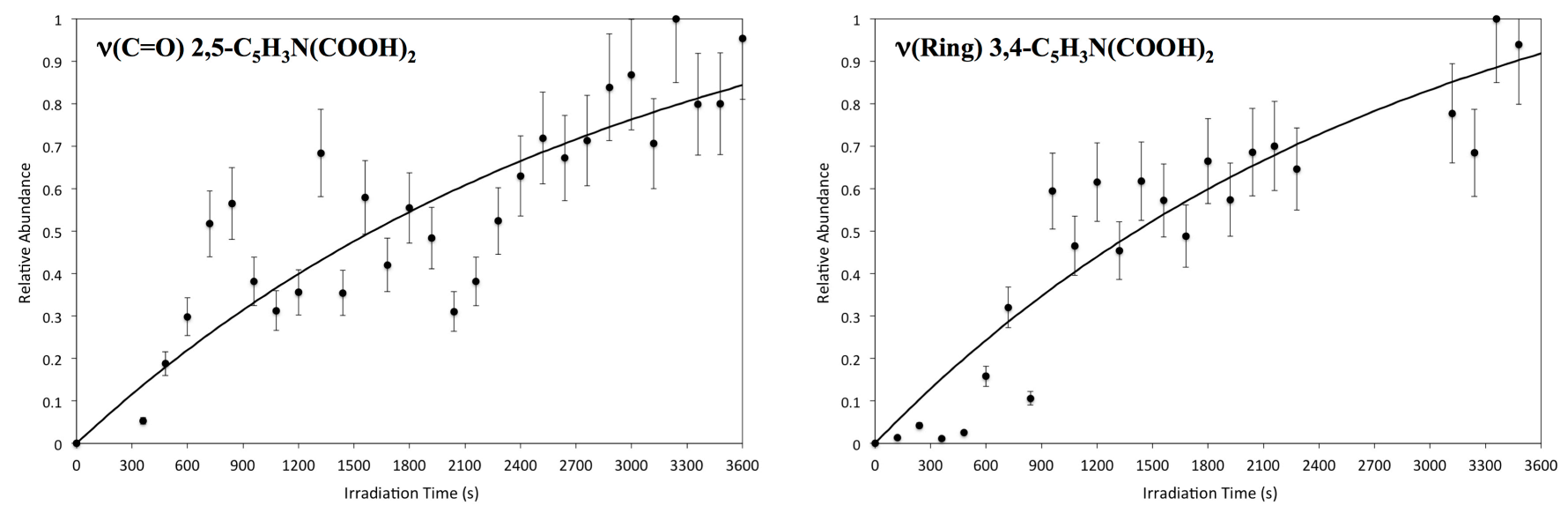